\title{
Contested Devotions: Space, Identities and Religious Dissent in the Apothecary's Home
}

\author{
Joanna Kostylo
}

The wave of religious reform that swept Italy in the first half of the sixteenth century challenged Catholic institutions, dogmas, ceremonies and everyday religious life in an unprecedented way. Mingled with the influence of Erasmus and northern Protestantism, it mobilised people regardless of class, gender or educational status to express their religious needs and to interpret the meaning of the sacred for themselves, wishing to 'live according to their own brains', ${ }^{1}$ to 'pray quietly at home' with no need for 'decorated altars and sounding bells of the material churches,' as some of them declared. ${ }^{2}$

Well before the events of the Reformation, the laity turned their homes into a refuge from the devotional formalism of the institutional Church. While often inspired by civic cults and other forms of communal piety, the laity actively and creatively interpreted their relation to the divine in the domestic sphere. ${ }^{3}$ But as confessional lines hardened in the wake of the Council of Trent (1545-1563), a concern for inward-looking spirituality, domesticity, solitude and isolation often turned into necessity. Thus when in 1575 the Venetian apothecary Silvestro Gemma shut the door of his pharmacy to isolate himself from the sound of the litanies and drama of the Corpus Christi procession, which

1 Archivio di Stato di Venezia (Hereafter ASv), Sant'Uffizio, b. 18, Dossier Gherlandi, 14 October 1561, fol. 15: 'perché vogliano viver secondo il lor cervello'.

2 Asv, Sant'Uffizio, b. 40, Dossier Nicolò Guidozzo, 11 February 1576, fol. 14r: 'sia meglio dir l'oratione in casa quietamente che in chiesa, per il tumulto delle persone'; b. 37, Dossier Ioannes Baptista Michael (1573) fol. 32r: 'tanto il far oration in casa et in altro loco, come andar in chiesa: et che l'andare ad essi tempi e chiese et ivi basar altari, ornarli, sonar campane, et altre cose che si fan in esse chiese materiali' non era 'necessario per la salute'. Cf. Seidel Menchi S., Erasmo in Italia: 1520-1580 (Turin: 1987) 104.

3 Vauchez A., The Laity in the Middle Ages: Religious Belief and Devotional Practices, ed. and intro. D. Bornstein, trans. M.J. Schneider (South Bend, IN: 1993); Kieckhefer R., "Major Currents in Late Medieval Devotion", in McGinn B. - Meyerhoff J. (eds.), Christian Spirituality: High Middle Ages and Reformation (New York, 1987) 75-108. For Italy specifically see, for example, Bornstein D., "Spiritual Kinship and Domestic Devotions", in Brown J.C. - Davis R.C. (eds.), Gender and Society in Renaissance Italy (New York: 1998) 173-192.

(C) JOANNA KOSTYLO, 2019 | DOI:10.1163/9789004375871_019

This is an open access chapter distributed under the terms of the prevailing CC-BY-NC-ND License at the time of publication. 
offended his Protestant ears and eyes, his religious experience was distinctively different from those who leaned over the windows to watch the flamboyant pageantry of civic processions, or lit fashionable cesendelli to illuminate the images of Virgin Mary which adorned their homes.

What did it mean, then, for the non-Catholic members of the community to experience their faith at home? While they were no longer able, nor willing, to look to 'material churches' for spiritual support and fulfilment, could they hinge their new religiosity on the existing rituals and patterns of domestic piety? And to what extent were their religious identities formed and informed by the everyday realities of family life and the material needs of the household, or performed in response to the religious and cultural pressures of the Church, which did not hesitate to dictate divine precepts in matters such as diet, health regimen and sexuality?

In this essay, I propose to explore these questions and sensibilities through various facets of domestic life, focusing on a particular kind of Renaissance household: the homes of Venetian apothecaries, where medical, domestic and devotional spheres converged. This in turn allows me to explore a broader set of considerations not usually considered in accounts of domestic piety, namely domestic health regimens, sexuality, dietary prescriptions, attendance to the sick, as well as communal reading of the Bible, music playing and other forms of organised sociability like participation in public processions. To document these various aspects I use Inquisition sources, which are naturally problematic, not least because they often denote the absence rather than presence of religious observance and expose irreverent behaviour and acts of iconoclasm. Yet this in itself provides a valuable insight into Catholic and non-Catholic assumptions about the right or wrong use of devotional texts, images and objects or other forms of expression, while the scrupulous investigations of the Inquisitors allow us to enter the private lives and spaces of ordinary people and discover what it meant for them to be a 'good Christian' or to live 'like a beast' in one's home.

In sixteenth-century Italy, apothecaries were expected to be on call at night and keep their botteghe open on Sundays and public feasts to ensure that essentials such as medications, wax torches for funerals and civic processions and other necessities were readily available. This meant that apothecaries usually lived above their workshops, running households in which the boundaries 
between occupational and domestic space were blurred. ${ }^{4}$ Hence, apothecaries were often defined as those 'who live at home or in the drugstore' ('vive in casa o nell'Apotheca'), as the family of the aromatarius Zuan Donato of Vicenza was described. ${ }^{5}$ The composite household of Silvestro Gemma, the owner of the pharmacy at the sign of the Two Doves (li do Colombi, le Colombine), which was operational in Venice from ca. $155^{0}$ until $165^{\circ}$ is another case in point. ${ }^{6}$

This was a medium-sized Venetian house situated in Rio Terrà della Maddalena near the church of San Marcuola, and consisting of the ground floor workshop and retail outlet lining the street, and the two-storey multifamily unit above. The parents Silvestro and Elena Gemma lived there with their four children: young Lucietta and her sister, and two adult sons Gian Battista and Marcantonio, who brought their wives Aurora and Marietta into the paternal home. ${ }^{7}$ As was the case in many artisanal shops, the Gemmas had a small labour force of apprentices (garzoni), Piero of Milan and Zuan and Martino of Treviso, living on the premises. They all lived together and helped

4 On the illegal trade and production of drugs at night see, ASv, Provveditori alla Sanità, Capitolari, b. 6, nr 20, 20 November 1310, published in Monticolo G., I capitolari delle arti veneziane sottoposte alla Giustizia e poi alla Giustizia Vecchia, dalle origini al 1330 (Rome: 1896). For night duties and opening times of Venetian pharmacies as distinct from other shops, see Welch E., Shopping in the Renaissance. Consumer Cultures in Italy, 1400-160o (London and New Haven: 2005) 112; Welch E., "Space and spectacle in the Renaissance Pharmacy", Medicina e storia 15 (2008) 127-158 (135). For parallel cases of bakers and other artisans who lived above their shops see Palumbo Fossati I., Dentro le case. Abitare a Venezia nel Cinquecento (Venice: 1984); and Cavallo S., "The Artisan's Casa", in Ajmar-Wollheim M. - Dennis F. (eds.), At Home in Renaissance Italy, exh. cat. (London: 2006) 352-355. On the fluidity of domestic boundaries see the fundamental work of Cohen E.S. - Cohen T.V., "Open and Shut: The Social Meanings of the Cinquecento Roman House", Studies in the Decorative Arts 9/1 (Fall - Winter 2001-2002) 61-84.

5 Asv, Sant'Uffizio, b. 6, Dossier 'Il Colombina.'

6 Silvestro Gemma and his heirs continued to run their shop well into the next century, and his grandson Giovanni Francesco Gemma is still recorded at li do Colombi in 1621 (see infra). A note dated 1650: Delle Insegne di Botteghe nelle quali già si soleva esercitare la professione di specier Medicinale, et hora sono serrate (Venice, Museo Civico Correr, Mariegola A., c. 279), which enlists li do Colombi as no longer active, provides terminus ante quem for the closure of this pharmacy. Cf. Dian G., Cenni storici sulla farmacia veneta, 7 vols. (Venice: 1900-1908) vol. 5 (1905) 36.

7 On this family see, ASv, Sant'Uffizio, b. 20, Dossier 'Zuanbattista Gemma'; b. 37, Dossier 'Gemma, Giò Battista; b. 8o, Dossier 'Per Domo Marco, Gemma Aurora'. See also, Martin J.J., Venice's Hidden Enemies (Berkeley and Los Angeles: 1993) 140-141; Ambrosini F., Storie di patrizi e di eresia nella Venezia del '50o (Milan: 1999) ad vocem. On their pharmacy as a site for heterodox activities, see Kostylo J., "Pharmacy as a Centre for Protestant Reform in Renaissance Venice", Renaissance Studies 30/2 (2015) 236-253. For pharmacies as centres of unorthodox discussions see, de Vivo F., "Pharmacies as Centres of Communication in Early Modern Venice”, Renaissance Studies 21/4 (2007) 504-552. 
to run the pharmacy, which was interchangeably called a home, spice shop, apotheca and dye factory (casa, spiciaria, apotheca, bottega, tintoria) to denote its multiple functions and spheres of activities.

Daily life in this pharmacy involved the constant transgression of boundaries between commercial, social, familial and religious spheres, in and around this shop. Gian Battista Gemma was known in his neighbourhood as a zealous 'Lutheran', haranguing his clients about religion. The conversations easily spilled out into a contested terrain of doorways and porticos. His intimate childhood friend Andrea Dandolo recalled that they 'would meet almost every day in that pharmacy, or in the streets.' 8 Moving through a dense network of passages, canals and bridges, they were seen proselytising at the Rialto bridge, the German fondaco and the orti of the Giudecca, a place of retreat where the whole group would 'take walks'. And vice-versa, the heterodox unrest that Gemma brought into the pharmacy was then cultivated within a domestic setting.

This family certainly had an interesting household structure, which reveals transgressive intimacies across different confessions and faiths, and raises important questions about early modern identity, gender, cultural hybridity and religious eclecticism. While the parents Silvestro and Elena were strongly associated with Lutheranism, their sons showed leanings towards Calvinism, while one of them, Marcantonio, brought a Catholic wife Marietta (de Bernardini) into the family. Similarly, their youngest daughter Lucietta, despite the influence of her family, had grown up to be a Catholic, at least after leaving the parental home and marrying Bernardino Forno. She would become the mother of Franceschina and Vicenzo Forno, who were both involved in the trial for heresy in 1625 against their aunt Aurora Gemma, the wife of Gian Battista. As the daughter of the Friulian physician Leonardo Clario, who ran from the Inquisition to the court of the Archduke Charles at Graz, and the sister of Giovan Battista Clario (ca. 1570-1617), a natural philosopher, fellow-student at Padua and cellmate of Tommaso Campanella, Aurora herself was 'a very shrewd woman, in her own right' as various witnesses recalled..$^{9}$ Influenced by the radical tendencies of the Spiritualists, Anabaptists and Antitrinitarians, she shared with her husband Gian Battista a set of sectarian views on the mortality and transmigration of the souls, the human nature of Christ, and denied

8 Asv, Sant'Uffizio, b. 23, Testimony of Andrea Dandolo, 1 September 1568: 'costoro pratticavano quasi ogni giorno nella detta spiciaria [...], et per le strade'.

9 Asv, Sant'Uffizio, b. 8o, Testimony of Girolama de Scudi, 17 April 1625: 'lei è una donna molto accorta che sa bene il fatto suo'. On Giovan Battista Clario see Firpo M., Dizionario biografico degli Italiani (hereafter DBI), vol. 25 (Rome: 1982), sub. voc. 
the doctrine of Trinity. It might have been, in fact, Aurora who 'converted' her husband Gian Battista to her radical views. Her niece Franceschina recalled her mother Lucietta telling her that Gian Battista and Aurora 'believed in nothing'. ${ }^{10}$

In contrast to Franceschina, who turned into a devout Catholic and unforgiving witness against her maternal uncle and aunt, her brother Vicenzo followed in their footsteps. Banned from Venice, he joined Gian Battista and Aurora in exile in Poland where the couple found refuge from the Inquisition. ${ }^{11}$ After Gian Battista's death in 1608, Aurora returned to Venice with her nephew Vicenzo and her new husband Marco de Domo who became known as 'il Turco' because of his sympathies and upbringing as an adoptive child of a rich Ottoman family in Constantinople. When they settled in the village of Sovernigo near Treviso, Aurora was denounced by the villagers as a Lutheran because she wore a red hat in church in the Polish fashion ('all'usanza Polacca'). ${ }^{12}$ While she read the Polish Bible and radical Socinian texts at home, Marco de Domo made no secret of his attraction to Islam and, according to one witness, 'to keep that man happy, one had to talk about nothing else but the Turks, amongst whom he spent such a happy childhood that they were always on his lips, recalling them with sweetness and tears in his eyes.13

Finally, the location of the Gemmas' pharmacy in a marginal 'transition zone' of the sestiere of Cannaregio, adjacent to the Ghetto, encouraged further transgressions. ${ }^{14}$ In 1621, the son of Marcantonio, Giovanni Francesco Gemma, was implicated in the trial against a Portuguese physician and a baptized marrano Jew suspected of relapsing back to Judaism, Giorgio Francesco Diaz, whose children Gemma baptised. According to the testimony of the merchant

10 Asv, Sant'Uffizio, b. 80, Testimony of Franceschina, 11 April 1625. On the Anabaptists and Antitrinitarians of the Veneto see, Stella A., Dall'anabattismo al socinianesimo nel Cinquecento Veneto. Ricerche storiche (Padua: 1967); Stella A., Anabattismo e antitrinitarismo in Italia nel XVI secolo. Nuove ricerche storiche (Padua: 1969); and recently Addante L., Eretici e libertini nel Cinquecento italiano (Rome - Bari: 2010). For a useful synthesis see, Firpo M., "La 'porta' della Riforma: Venezia", in Riforma protestante ed eresie nell'Italia del Cinquecento. Un profilo storico (Rome: 1993) 11-28. For religious skepticism and unbelief see, Barbierato F., Politici e ateisti. Percorsi della miscredenza a Venezia fra Sei e Settecento (Milan: 2006).

11 Asv, Sant'Uffizio, b. 8o, Dossier 'De Domo Marco e Gemma Aurora di origine polacca'. Testimony of Andrea de Bernardis, 19 April 1625.

12 Ibid., Testimony of Padre Sebastiano Dono, Rector of the parish of Sovernigo, 29 April 1625 .

13 Ibid., Testimony of Girolama de Scudi, 17 April 1625: 'sentiva tanto gusto nel discorrer de Turchi che da dolcezza li venivano le lagrime dalli occhi'.

14 Braunstein P., "Cannaregio, zona di transito?", in Calabi D. (ed.), La città italiana e i luoghi degli stranieri, XIV-XVIII secolo (Rome: 1998) 52-62. 
Francesco Romano, the Gemmas hosted Diaz in their pharmacy and frequented his house where Jewish and Christian merchants and doctors met. ${ }^{15}$

\section{$2 \quad$ Instructing 'Brainless Girls'}

Marietta wholeheartedly disliked her brother-in-law Gian Battista, who was the 'worst of the whole family' and 'had been the ruin of that house.'. was not shy to describe her tangled relationship with her brother-in-law to her cousin Elisabetta, who compromised him before the Holy Office at the first opportunity. Marietta recalled that 'in the evening Gian Battista would recite verses from Lutheran books, and he had plenty of them', though we do not know which specific titles because they were all dumped in a canal when the Gemmas had learned that the Inquisitors were coming to investigate their house. ${ }^{17}$ We know, however, that Gian Battista read works by Melanchthon, Pietro Martire Vermigli, Calvin's Institutes and translation of the Bible, and popular devotional texts such as 'La speranza del Christiano', which were sold in great numbers at the Rialto Bridge as his patient Semprini told him. ${ }^{18}$

Communal reading of the Bible and other literature was welded onto existing domestic rituals such as family meals. 'Always at the table Gian Battista, the doctor, had a book in his hands, and they spoke against religion, as Elisabetta reported to the Inquisition, having attended family meals on the invitation of Marietta. ${ }^{19}$ The family talked about confession, intercession, the cult of saints, the meaning of the Eucharist, purgatory and other similar things, and Gian Battista, in particular, appeared to believe in nothing, certainly not in the Holy Church' ${ }^{20}$ A graduate in medicine, and the author of a treatise on bubonic plague, the Methodus rationalis novissima, atque dilucidissima curandi bubonis (1584), Gian Battista would have been directly influenced by the heterodox

15 Asv, Sant'Uffizio, b. 77, Dossier 'Giorgio Francesco Diaz'.

16 Asv, Sant'Uffizio, b. 37, Testimony of Elisabetta, 15 June 1575: 'Zuan Battista el dottor è stato lui la ruina de quella casa.'

17 Ibid.

18 Asv, Sant'Uffizio, b. 23, Dossier 'Sylvestrum Semprini, Angelam, Stephanum et Cypriani Semprini', Testimony of Cipriano Semprini, 3 January 1568. On the Semprini see Martin, Venice's Hidden Enemies 140-141; Ambrosini, Storie di patrizi ad vocem.

19 Ibid., b. 37, 'Denuncia di Elisabetta, cugina di Marietta, moglie di un spiciaro alle Columbine,' 15 June 1575: 'sempre quando si manzava quell Zuan Battista el Dottor haveva un libro in mano, et parlavano contra la religione’.

20 Asv, Sant'Uffizio, b. 37, Testimony of Elisabetta, 17 September 1574: 'Lui ha detto che non crede in niente, ne nella Santa Chiesa'. 
trends emanating from the neo-Aristotelian circles of Padua. ${ }^{21}$ As the only member of the family with a university degree, he felt entitled to assume the role of a tutor and a spiritual guide to his siblings, instructing them in the principles of faith with an air of intellectual superiority. His brother Marcantonio admitted that 'even though I liked to engage in debate with my brother, he continued to reproach me that I am too ignorant and should not speak about these matters.' ${ }^{22}$ His catechising did not leave out his two young sisters, 'the brainless girls' ('le pute che non hanno cervello'), as Elisabetta put it. While Lucietta was perhaps too young to follow, the other girl succumbed to the teaching of Gian Battista, who 'had twisted her brain'. ${ }^{23}$

The idea that parents, especially the male heads of the household, should act as tutors and spiritual guides to their offspring pervaded Reformation teaching on marriage and the family, and acquired a particular significance for the Italian dissidents who could not rely on parish schools and churches to pass down faith to the younger generations. The Italian humanist and suspected Antitrinitarian Celio Secondo Curione highlighted this fact. He wrote, 'you know how important it is to be born into and educated in a religion, and on many occasions it is more important to be educated than born'. ${ }^{24}$ The author of the Della Christiana creanza de' figliuoli (1545), Curione's educational ideas championed a series of religiously inspired vernacular tracts on domestic economy, including a conduct book for female students La institutione di una fanciulla nata nobilmente (1555) by Gian Michele Bruto. An apostate Augustinian friar, Bruto developed a following in Venice as a humanist educator and leader of a heretical schola at San Isoldo, where 'many priests, friars,

21 Gemma Joannes Baptista, Methodus rationalis novissima, atque dilucidissima curandi bubonis carbunculique pestilentis [...] (Graecij Styriae, Ioannes Faber: 1584). The work was composed during his exile in Gratz, where he joined his father-in-law in his duties as a court physician of Archduke Charles to whom the treatise was dedicated. There is a growing number of studies on the heterodox medical circles of Venice and Padua. For recent interpretations see especially Ferretto S., "In margine ad un fascicolo processuale (15581561): Ippolito Craya, Pomponio Algieri e la cultura padovana nel Xvi secolo", in Olivieri A. (ed.), Le trasformazioni dell'umanesimo fra Quattrocento e Settecento. Evoluzione di un paradigma (Milan: 2008) 155-167; Quaranta A., "Umanesimo medico e culture confessionali nell'europa del Cinquecento. Carteggi inediti (1560-1587) di Girolamo Donzellini, 'Physicus et Philosophus', Giornale di storia 15 (2014) 1-34.

22 Asv, Sant'Uffizio, b. 20, Testimony of Marc'Antonio, 2 June 1565.

23 Asv, Sant'Uffizio, b. 37, Testimony of Elisabetta, 15 June 1575: 'a sua sorella haverla voltato 'l cervello'.

24 Cf. Landi A., "Il pensiero pedagogico degli eretici italiani del Cinquecento", Bollettino della società di studi Valdesi 144 (1978) 45-52 (46). For a recent biography of Curione see, Biasiori L., L'eresia di un umanista. Celio Secondo Curione nell'Europa del Cinquecento (Rome: 2015). 
and others gather to debate against the Catholic faith', among them none other than Gian Battista Gemma. ${ }^{25}$

It has been argued that the Protestant emphasis on the conjugal couple as the basis of the 'holy household' emancipated women from roles as relatively 'unsophisticated' and passive worshippers to become conscious and piously engaged readers of the Bible. ${ }^{26}$ However, while the Reformation call for sola Scriptura shifted the emphasis from devotional image to written word, the Protestant message of female empowerment should not be overemphasised. ${ }^{27}$ Indeed, Bruto's conduct book was a compilation of fairly conventional theories about female education that reasserted the traditional patriarchal order within the family. It recommended literacy for the acquisition of female virtues of chastity, piety and humility, and was later translated by Thomas Salter as the Mirrhor of Modestie (1579). Gemma did not need to read Bruto's book to share his assumptions that male heads of the household should instruct their wives, sisters and daughters. Grounded in contemporary medical and scholastic (Aristotelian) conceptions of the physiology of reproduction and sexual difference that imparted an image of women as experiencing the world corporeally through their instincts and senses rather than intellect, ${ }^{28} \mathrm{Gemma}$ took time to educate his sisters and turn them away from 'brainless' adoration of images that for him they stood for specifically 'feminine' visual and material idolatry cult of the Holy Virgin. ${ }^{29}$

25 ASv, Sant'Uffizio, b. 18, 20 June 1562; b. 20, 19 May 1565. On the fundamental role of schoolmasters in the spread of heresy see, Seidel Menchi's chapter "Scuola di grammatica, scuola di eresia" in Erasmo in Italia 122-142.

26 Roper L., "The Holy Household: Women and Morals", in Reformation Augsburg (Oxford: 1989); and Seidel-Menchi, Erasmo in Italia 176-191 on re-evaluation of marriage and domestic piety in Italy.

27 Frigo D., Il padre di famiglia. Governo della casa e governo civile nella tradizione della 'economica' tra Cinque e Seicento (Rome: 1985); Cameron E., "'Civilized Religion': From Renaissance to Reformation and Counter-Reformation", in Martin J.J. (ed.), The Renaissance: Italy and Abroad (London and New York: 2003) 297-316.

28 Maclean I., The Renaissance Notion of Woman: A Study in the Fortunes of Scholasticism and Medical Science in European Intellectual Life (New York: 1980).

29 Fortini Brown P., Private Lives in Renaissance Venice: Art, Architecture, and the Family (New Haven and London: 2004). On the specific demands of female spirituality, and their ability to experience the divine in the context of the emerging notion of self, see Mazzonis Q., Spirituality, Gender, and the Self in Renaissance Italy (Washington D.C.: 2007), esp. ch. 5: 178-213 with further bibliography. 
Displaying and illuminating images of the Holy Virgin, reciting rosaries, kneeling, touching or kissing holy images and objects all played a critical role in the transmission of didactic piety in the Catholic home in sixteenth-century Venice. Nothing of this could be found however in the Anabaptist household of the apothecary Ambrogio 'in the contrada of San Geremia in Cannaregio by the ponte de legno' (Ponte delle Giulie), who stripped the walls of his home bare of pious images and other paraphernalia of devotion. This was the case until he married a 'Christian' wife and succumbed to her wishes, 'having bought her one painting meant for the devotion of the mother of our Saviour Christ, though he never allowed her to light a cesendello in its honour and glory', as his next-door neighbour Isabetta, the wife of a Venetian trader, Giacomo, reported. ${ }^{30}$

During their hearing before the Inquisition Giacomo was less concerned about his neighbour's domestic interiors than his wife Isabetta, who felt particularly offended in her sensitivities, denouncing Ambrogio for living like a beast rather than a Christian', without fear of God and in disrespect of sacred laws, and never making the sign of the cross. ${ }^{31}$ Above all, Ambrogio 'has always insisted that there should be no painting in his home, whether of our Madonna, or of the saints, holding in contempt all venerations and public feasts dedicated to them by the Holy Mother Church'. ${ }^{32}$ Ambrogio disrespected the feasts of the Holy Sacrament and ridiculed those who celebrated jubilees and participated in plenary indulgencies on feast days. ${ }^{33}$

The ritualistic pageantry that developed around public feasts and Corpus Christi processions was an important aspect of communal piety, with Venetian

30 ASv, Sant'Uffizio, b. 22, Dossier 'contra Ambrosium Aromatarium, 18 December 1567: 'ch'avendosi maridato et tolto una cristiana la ne ha portato uno [quadro] avendo in devotion la madre del nostro Salvatore Christo ma però non volendo mai che se imipizi [accende] un cesendelo a honore et gloria sua farlo'. In Venice, cesendelli, were used both as votive lamps hanging above the altar and for illuminating the altarpiece and as private illumination of holy pictures in the home, particularly those with the image of the Virgin. They had distinctive elongated form, typical of an Eastern style, and were also fashionable in Istanbul, not surprising given Venice's long standing ties with the Middle East. Palumbo Fossati I., "La casa veneziana", in Toscano F. - Valcanover F. (eds.), Da Bellini a Veronese. Temi di arte veneta (Venice: 2004) 443-492 (473).

31 Ibid., 'vivendo come una bestia fuor della sacra religione Christiana'.

32 Asv, Sant'Uffizio, b. 22, Denuncation of Antonio de Zuan Padovano, 18 December 1567: 'mai non ha voluto che in casa sua stiano quadri niuno, così de nostra [Ma]dona sì come de santi desprezando quello ch' la santé madre giesa ne fanno grande commemorationi et feste'.

33 Asv, Sant'Uffizio, b. 22, Testimony of Donna Isabetta, mogier del sopradetto Giacomo compravendi veneziano, 20 December 1567. 
people following en masse through the city's townscape, singing litanies to the Virgin Mary and honouring the real presence of Christ in the consecrated host in a sealed monstrance which was paraded through the campi and streets. It was an occasion to show devotion in a very public way and to meet one's neighbours and join in celebrations, although women were often restricted to watching the razzle-dazzle of these events from the safe distance of their balconies and windows. But the lack of external gestures of reverence from one's neighbour could be observed from anywhere. Overlooking the street from her balcony during the Corpus Christi procession, Isabetta noticed that the apothecary Ambrogio did not even remove his hat when the monstrance with the Holy Sacrament was passing. ${ }^{34}$

A few steps away at San Marcuola, the apothecary Silvestro Gemma was also singled out for his lack of reverence during public processions. When everybody closed down their shops and joined in to sing litanies, Silvestro would throw a thousand curses on popes, bishops, patriarchs and their excesses and complain that he could not bear listening to those litanies, which were all pageantries. ${ }^{35}$ Nor did the rich imagery associated with the cult of Virgin Mary have any place in the Reformed household of the Gemmas, who, like Ambrogio, cleansed their home of idols and superstitious objects. According to Marietta, at the table Gian Battista was, 'always holding the book of the Gospels in his hand, instructed them about images, saying that in the Gospels the Lord God cursed the idols, that St Daniel was the enemy of all idol-worshippers and that the images of Madonna and the saints were idols.' ${ }^{36}$

In the Protestant home of the Gemmas the demarcation of religious identities was set by the male members of the family and leaned towards an internalised form of religiosity. Marietta struggled to produce her own (Catholic) values and meanings within the shifting multiple religious allegiances of this heterodox family, to which she had been appended by marriage. The experience of the Catholic wife of Ambrogio, who was never allowed to light a votive lamp in honour of the Virgin Mary, must have been similar. When Ambrogio

34 Ibid., On women's role in public processions see, Muir E., Civic Ritual in Renaissance Venice (Princeton: 1981) 303.

35 ASv, Sant'Uffizio, b. 37, Denunciation of Elisabetta, 15 June 1575: 'diceva, che le erano tutte manierie, et non poteva sentir quelle letanie che si dicevano'.

36 Ibid., 'parlava delle imagini et che sempre haveva el libro delo Evanzelij in man, et diceva che nelli evanzelij el S.r Dio malediceva l'idoli, et parlava de S. Daniel, che non volesse adorar l'idoli, et che le imagini della Maria et di Santi sono idoli'. Daniel, the hero of the Book of Daniel [2:34-35] was best known as the prophet who received apocalyptic visions and interpreted the dream of the Babylonian king Nebuchadnezzar of a giant iron statue smashed by a stone from heaven. His interpretation of the dream was used against idols and idol-worshipers. 
threw a painting depicting 'la passion di Christo' into a canal and cut another one into pieces in front of his wife, mother and a domestic servant, his neighbours wondered why the women 'said nothing'. ${ }^{37}$ Religious identities could seal marriages and friendships as well as disintegrate them. The fabric dyer Zuan Zapelin of Milan explained that he had always regarded Marcantonio Gemma as his good friend and would have continued to do so had he not been forced by his confessor to make a denunciation to the Holy Office. Their friendship ended in a row with Marcantonio threatening Zuan Zapelin and shouting 'I hope you realise that you have ruined my life', as the latter reported. ${ }^{38}$

Similarly, Marietta's marriage and relationship with Marcantonio's family was anything but serene. She revealed to her cousin Elisabetta that every time she wanted to go to church for confession and communion, she would tell them that she was visiting her sisters, because 'in the house of those at the Collombine they would yell at her, shouting blasphemies against confessions and communion'. ${ }^{39}$ At home, she used to recite Paternosters and Ave Marias to a rosary, but 'no matter how many rosaries they found in her hand, they would throw all of them away'40

The chasm that developed between Protestant and Catholic members of this family was also due to the underlying tensions between specifically gendered forms of devotion, with their respective aesthetics and sensitivities. One evening, after hearing a sermon by a Servite friar, Gian Battista criticised the friar 'because he talked too much about the Madonna'. Pointing out that Mary 'had been a woman as any other', he implored that 'one should not give sermons about the Madonna, which are for women, but preach instead about Christ' ${ }^{41}$ For Gian Battista, the friar appeared to repeat mindlessly the same things like a beast saying over and over again Madonna, Madonna [...] as if the bastard had no Christ to preach about'.42

37 ASv, Sant'Uffizio, b. 22, Testimony of Giacomo compravendi veneziano, 20 December 1567.

38 Asv, Sant'Uffizio, b. 20, Testimony of Zuan de Giacomo Zapelin Milanese, 24 May 1565: 'et $\mathrm{mi}$ ha minacciato, et detto advertissi [sic] che mi hai rovinato el mondo'.

39 ASv, Sant'Uffizio, b. 37, Denunciation of Elisabetta, 15 June 1575: 'ogni volta che si voleva confessar, et co[mun]icar [diceva di] venire a casa di queste sue sorelle et diceva di far questo per causa, che in casa de questi dalle Colombine si facevano beste[mmie] di confessione, et co[mun]ione, et le cridavano'.

40 Ibid., 'che quante corone ghe trovavano in mano a costei tutte ghe le battavano [sic] via'.

41 Asv, Sant'Uffizio, b. 20, Testimony of Donna Franceschina, 27 June 1574: 'non bisogna predicar tanto della Madonna, che queste sono prediche de femene: bisogna predicar di Christo'.

42 Asv, Sant'Uffizio, b. 20, Testimony of Ambrosio Mediolanesi, sanitarius Venetiano, 12 May 1565 . 
The repetitious and mindless nature of Catholic devotions was often a target of Protestant attacks, with Erasmus's Encomium Moriae and Enchiridion providing a plethora of polemical weapons. Reciting combinations of Paternosters and Ave Marias was intended to provide a simple structure around which to create one's prayer, while the mnemonic pattern of repetition was intended to assist particularly women, children and the illiterate in committing to memory the fundamental prayers and Catholic doctrines. In the preface to a popular early sixteenth-century rosary manual, Alberto da Castello explained that 'in order to memorise and remember, and to contemplate these mysteries,' he illustrated them with 'depicted histories' so that they would serve 'not just the literate, but equally the illiterate, unlearned, and idiots ...')..$^{43}$ In order 'to carry these holy mysteries always in their heart and recite them continually', he recommended copying particular passages from the book or, in the case of those who could not read, tearing out the illustrations and fixing them to the doors. ${ }^{44}$ These prescriptions reveal that rosaries could be used as a pedagogical device for a relatively 'unsophisticated' range of consumers. But not everybody saw a didactic value in these mnemonic strategies of repetition. Friar Daniele of Brescia was accused of 'turning [the ordered life] of pious women upsidedown by saying that they should not recite the rosary because it was presumptuous to calculate the number of prayers to God'.45

These attacks were also linked to changing Reformation tastes and aesthetics. The growing naturalism of Renaissance religious imagery created resistance to the artistic modes of capturing divinity through anthropomorphism. Gian Battista declared that in the Old and New Testaments there is no evidence that God has ever been seen, and ridiculed those 'who depict God as an

43 Alberto da Castello, Rosario della Gloriosa Vergine Maria (Venice, Marchio Sessa \& Piero di Rauani compagni: 1522) fol. 8r: 'Imperochè [...] di rammemorare et ricordarvi, et contemplare questi misterij i quali non solamente con la lettera et approbatione per le divine scritture, ma etiando con le historie figurate possiate vedere quel che havete a contemplare. Et questo non solamente a i letterati, ma etiam alli illeterati, ignoranti, et idioti [...]'.

44 Ibid., 'Fate che habbiate questi misterii sempre ne' vostri cuori per continua recordatione de quelli e narrereti quelli a gli vostri filgioli insegnandoli a dire questo Santo Rosario, [...] che sempre haverete in mano, i quali sempre moverete dinanzi a gli occhi vostri, dicendo i Pater nostri, et Ave Marie, et gli scriverete sopra le porte, e nelle porte delle case vostre, mettendo le figure di questo Santo Rosario sopra di esse, e per le case vostre in continua memoria'.

45 Asv, Sant'Uffizio, b. 159, Dossier 'Contra fra Danielem de Brixia', fol. 14r, 8 October 1554: 'per aver mettuto tutte le donne sottosopra, dicendo che elle non debbano [...] dir corone, perché l’è prosontion numerar le oration a Dio'. Cf. Seidel Menchi, Erasmo in Italia 386n. 
old man, as if he could no longer move or was just about to die. ${ }^{46}$ Similarly, commenting on paintings which focused on the maternal figure of Madonna with Christ as a helpless infant, he said that venerating such images was nothing more than venerating a piece of wood ('come si adora quell legno si adora madre di Christo'), and implored worshippers to adore only 'Christo, Christo, Christo et Christo'. 47

This relentlessly Christocentric piety which focused on Christ's sufficiency for salvation was at the centre of Reformed sensitivities and identities. Although we do not have an account of the domestic interiors of Gian Battista's pharmacy in Venice, a detailed description of his wife Aurora's home, which she set up with her second husband Marco, yields more information. During the trial of 1625 , they were accused of 'living like irrational animals. ${ }^{48}$ According to Girolama de Scudi, the mother-in-law of Aurora's nephew Vicenzo, she witnessed 'no act or sign' of Christian devotion during their extended family visit. She had never seen Aurora with a rosary in her hand, nor praying or saying the offices in honour of the Madonna. In the camera on the ground floor, the principal room where sleeping, eating, domestic chores and leisure activities would take place, and where the aged Aurora spent most of her time, Girolama found no holy images or objects that would indicate that her home was a place of Christian worship. ${ }^{49}$ Instead, the couple was heard mocking the thaumaturgic powers attributed to the statue of the Madonna in a village chapel ('una Madonna di un Capitello [...] che faceua miracoli'). When a domestic servant Cattarina asked their permission to take her crippled son to the chapel and pray for the miraculous healing of his knees which were 'disfigured and twisted outward', they began to laugh and mocked miserable Cattarina: 'Don't you know how to further mess up your son? But if you insist go ahead and accompany him cripple to return him even more twisted [by such superstitions]. 50

A daughter, sister and a wife of physicians with strong Spiritualist Anabaptist traditions, Aurora's assault on the healing employment of sacred images - an

46 Asv, Sant'Uffizio, b. 20, Testimony of Ambrosio, sanitarius Venetiano, 12 May 1565: 'costoro lo depenzaono vecchio, che 'l par che 'l non se possa movere, et che 'l voglia morir l'hora in hora'.

47 Asv, Sant'Uffizio, b. 20, Testimony of Francesco Penci, barbiere, 27 June 1574.

48 Asv, Sant'Uffizio, b. 80, Dossier 'Per Domo Marco, Gemma Aurora', 15 April 1625: 'vivono proprio come animali irrationali'.

49 Asv, Sant'Uffizio, b. 80, testimony of Girolama de Scudi, 17 April 1625: 'Quanto alla donna vi non l'hò mai veduta ne con corona in mano, ne à dirla, ne à dir l'off[ici]o, ne à far oratione. et nelle stantie da basso dove habitava non teneva alcuna imagine di devotione, ne lei faceva atto ò segno alcuno da Xristiana'.

$5^{\circ}$ Ibid., 'Non sapete come far stupiar più questo vostro figlio? Et se volete andar, voi lo menate zotto, lo ritornate storppiato' [storpio]. 
issue upon which the members of this medically informed family might have been particularly sensitive - does not surprise us. Indeed, the only sacred object that Girolama noticed in Aurora's house was kept in the room upstairs: 'a Christ with Death underneath, but to which neither worship nor reverence was paid, just as if it had not been in that house. ${ }^{51}$ Images representing the crucified Christ with a skull at the base of the crucifix were fashionable throughout Reformation Europe. The sobriety of such images was befitting contemplation of one's death and Christ's sufficiency for salvation in accordance with more ascetic Reformed patterns of piety and aesthetics. Given the monotheistic and iconoclastic aspect of Aurora and her Turcophile husband's beliefs, however, it was charged with yet another set of connotations. In striking contrast to the morbid anxiety about death and salvation that pervaded contemporary wills and culture, Aurora was heard saying that Paradise and Hell did not exist and 'that it was great folly to believe in the holiness of Our Lord because he was a man. ${ }^{2}$ The couple spoke instead of reincarnation and 'that there are only seventy-one heavens and when the soul dies, it goes to one of those heavens.' ${ }^{53}$ The idea of seventy-one heavens was an Islamic conception of paradise - an eternal Garden (al-Jannah). According to Islamic eschatology, Jews, Christians and Muslims would split into 71,72 and 73 sects respectively, but only one sect of Christians, one sect of Jews and one of Muslims would enter al-Jannah. ${ }^{54}$

Leaving aside the fascinating Antitrinitarian, Socinian, Turkish and Polish origins of their eclectic mix of beliefs, the rejection of aspects of religion that appeared to be ritualistic and visual, and the denial of the divinity of Christ, would undoubtedly bring allegations of adhering to a monotheistic and iconoclastic faith such as Islam. Such accusations were not unusual in early modern Venice, a transition point between East and West exposed to constant traversal of thresholds between Catholic, Protestant and Ottoman cultures.

The 'Turk' became a trope through which both Catholic and Protestant apologists accused one another of idolatry to further their own religion against both their Christian opponents and Muslims. Luther saw the figures of the Turk and the Pope as interchangeable under the common denominator of Antichrist. In his 1535 lectures on Genesis, he declared that the 'Antichrist is at

$5^{1}$ Ibid., 'ma nel soler di sopra heueua in casa in una camera un Christo con una Morte sotto, che però non era adorato ne riuerito tanto quanto non fosse stato in casa'. ASv, Sant'Uffizio, b. 8o, Testimony of Vicenzo Forno, 22 April 1625: 'che era pazzia grande il prestar fede alla santità di N.S.re perchè era huomo'.

53 Asv, Sant'Uffizio, b. 8o, Testimony of Antonio Valvason, 11 April 1625.

54 Abul Quasem M., Salvation of the Soul and Islamic Devotions (London: 1983) 19-20. 
the same time the Pope and the Turk. ${ }^{55}$ Catholics, in their turn, claimed that Luther was no better than Mahomet because they both spoke against idols, a point that was made during a discussion when Gian Battista Gemma sought to explain 'the origins of Martin Luther' to a hygienist (sanitarius) Ambrogio of Milan. In defence of Luther against 'all these malicious opinions', Gian Battista instructed his young neophyte that 'Martin has not acted in the same way as Mahomet, but preached out of pure zeal, and for the cause of indulgences and against falsehoods. ${ }^{56}$

If the flamboyant drama of Catholic pageantry offended the Protestant ears and eyes of the Venetian apothecaries, by contrast in sixteenth-century Venice everyone sang psalms and songs in churches and at home, and so did the Gemmas. ${ }^{57}$ Gian Battista's friend Andrea Dandolo admitted that he was a frequent guest in their house because of his passion for music: 'I cannot play the music but I like to listen [...] so I often came to listen to Gemma who can sing and play. ${ }^{58}$ When interrogated about the nature of these performances, another witness, Alvise Mocenigo, revealed that they involved singing psalms to the improvised accompaniment of Gian Battista who played the lute, with the physician Teofilo Panarelli reciting passages from scriptures and interpreting their meaning. ${ }^{59}$ Dandolo confessed that he liked these recitations because they were 'simple translations in vernacular verse'. ${ }^{60}$ These were vernacular psalms: 'espositione sopra li salmi' in the condemned version of Antonio Brucioli, which Gemma's patient Francesco Semprini kept hidden in the wall

55 Dr Martin Luther's Werke: Kritische Gesammtausgabe (Weimar: 1883-) vol. 3, 121. Barnes R.B., Prophecy and Gnosis: Apocalypticism in the Wake of the Lutheran Reformation (Stanford: 1988) 42.

56 Asv, Sant'Uffizio, b. 20, Testimony of Ambrosio Mediolanesi, 12 May 1565: 'che Martino non haveva fatto come Machometto, ma haveva predicato per puro zelo, et causa le indulgenzie, come contra cose false'.

57 On singing hymns, psalms and litanies in Venetian churches and confraternities see Fenlon I., Music and Culture in Late Renaissance Italy (Oxford: 2002).

$5^{8}$ Asv, Sant'Uffizio, b. 23, 1 September 1568.

59 Asv, Sant'Uffizio, b. 23, Testimony of Alvise Mocenigo, 12 July 1568. For the leading role of Panarelli in the elite conventicles of Venice see, Grendler P.F., The Roman Inquisition and the Venetian Press, 1540-1605 (Princeton: 1977) 104-105, 134-140; and Ambrosini F., “Tendenze filoprotestanti nel patriziato veneziano", in Gullino G. (ed.), La Chiesa di Venezia tra Riforma protestante e Riforma cattolica (Venice: 1990) 155-181.

6o Asv, Sant'Uffizio, b. 23, Dossier D. Andream Dandulo, 1 September 1568. 
of his house. ${ }^{61}$ Like Clément Marot's French paraphrases of psalms printed in Lyon ca. 1530, Antonio Brucioli's vernacular Bible, published in Venice in 1532, promoted the knowledge of the Old Testament and the Psalms among Italian reformists, including Gemma's circle who met to sing Protestant songs at the German fondaco and the Giudecca gardens. ${ }^{62}$ It would be fascinating to know whether they were sung to the existing psalm-melodies or set to new tunes.

Like recitation of the rosary, singing was a powerful mnemonic exercise to help the faithful to memorise key devotional texts, which were more easily absorbed through musical phrases and song metrics, and both Catholic and Protestant communities exploited the melodic capital of vernacular songs for devotional and didactic purposes. ${ }^{63}$ Communal singing provided a moment of shared ritual experience that played an important role in affirming confessional identities among Gemma's family and friends as a group, who otherwise lived the marginalised and fragmented lives of religious dissenters.

These ephemeral audio events are difficult to capture; but we do have a detailed account of one intimate performance in the home of Gian Battista's friend Giacomo Negron, a flute player ('sonador di pifaro'). One day, as Gian Battista's friend and musically-minded fellow physician Lodovico Abbioso recalled, he was invited by Negron to his house to meet a group of foreign musicians:

So, after supper, we gathered in a big room where all of them were holding violas in their hands. I did not know anybody except Giacomo, who handed me a viola and we began to play and sing. At this moment when we played, Paulo Moscardo and Teofilo Panarelli joined us and sat to

61 Asv, Sant'Uffizio, b. 23, 3 January 1568. On the importance of Brucioli's Bible: La Biblia quale contiene i sacri libri del Vecchio Testamento, tradotti nuovamente da la hebraica verità in lingua toscana da Antonio Brucioli [...] (Impresso in Vinegia, ne le case di Lucantonio Giunti fiorentino: 1532), see Del Col A., "Il secondo processo veneziano di Antonio Brucioli", Bollettino della società di studi valdesi 49, 146 (1979) 85-100; Del Col A., "Il controllo della stampa a Venezia e i processi di Antonio Brucioli (1548-1559)", Critica storica 17 (1980) 457-510.

62 Seidel Menchi S., "Protestantesimo a Venezia", in La Chiesa di Venezia 131-154. For Marot, see Wursten D., Clément Marot and Religion: A Re-Assessment in the Light of his Psalm Paraphrases (Leiden - Boston: 2010).

63 Pollmann J., "Hey Ho, Let the Cup Go Round!' Singing for Reformation in the Sixteenth Century", in Schilling H. - Tóth I.G. (eds.), Cultural Exchange in Early Modern Europe (Cambridge: 2006) vol. 1, 294-316 (301). For the Reformation as a 'multimedia' phenomenon see Scribner R.W., For the Sake of Simple Folk: Popular Propaganda for the German Reformation (Cambridge: 1981). See also the essays by Remi Chiu, 27-44, and Iain Fenlon in this volume, 89-114. 
listen to music. After the musicians left, we remained alone, four of us, and Teofilo took the New Testament out and a writing that he kept up his sleeve, which was his commentary on the passage 'In principio erat Verbum' from John's Gospel. He asked us to listen while he recited. And then we left. ${ }^{64}$

Since Lorenzo Valla, Marsilio Ficino and Erasmus had taken issue with Jerome's Vulgate Bible, the exegesis of the Prologue to John's Gospel 'In principio erat Verbum' had become a central issue in theological debates on the two natures of Christ, as the eternal Logos-Son consubstantial with the Father, or as a man (who did not exist before he was born of Mary). With their respective Platonic and Aristotelian metaphysical presuppositions, these speculations became pertinent to Eucharistic and Antitrinitarian controversies of the Reformation. ${ }^{65}$ While we do not know the content of Panarelli's commentary, the mixing of theology and home entertainment that took place at Negron's house certainly helped to disseminate heterodoxy in the homes of Venetian artisans. Gian Battista and his friends waged the battle for the Reformation in their homes, but also in taverns, streets and city squares, where the role of music and song as a propaganda tool mattered greatly. No wonder, then, that they made friends with Giacomo Negron and his band called 'the Favretti', who developed a following not only as street musicians but also as street theologians, unsettling the urban public with their unorthodox behaviour. In 1548, two members of

64 Asv, Sant'Uffizio, b. 32, Dossier 'Panarelli Teofilo ed Abbioso Lodovico', Testimony of Lodovico Abbioso, 24 May 1568: 'et così il dopo disnar andai da lui, et andassemo in una sua camera grande ove erano alquanti con le viole in mano, il quali io non conosceva salvo messer Giacomo, et ne tolse anca mi una viola in mano, et si mettessemo a sonar et a cantar. In questo mentre venne Paulo Moscardo et Theofilo Panarelli, et stette ascoltar la musica, et partiti detti musici restassemo noi quattro soli, et messer Theofilo cavò fuori il Testamento nuovo et una scrittura che l'haveva in manica, et disse che l'haveva fatto sopra l'Evangelio di S. Zuane sopra l'In principio erat Verbum, il quale ne pregò che dovessemo ascoltar, et così lo lesse; [et] dapoi se partisemo'. See also Ambrosini, Storie di patrizi 231-232.

65 Fragnito G., La Bibbia al rogo. La censura ecclesiastica e i volgarizzamenti della Scrittura (1471-1605) (Bologna: 1997). For Valla see, Camporeale S.I., Lorenzo Valla. Umanesimo e teologia (Florence: 1972); for Ficino, Trinkaus Ch., In Our Image and Likeness: Humanity and Divinity in Italian Humanist Thought (Notre Dame: 1995) vol. 2: 740-741. For Erasmus, see O'Rourke Boyle M., Erasmus on Language and Method in Theology (Toronto: 1977) 19-21; and Rummel E., Erasmus' Annotations on the New Testament: From Philologist to Theologian (Toronto: 1986). For Eucharistic controversies see below. 
this band were arrested when they recited texts denying the doctrine of free will in front of the Church of San Giobbe. ${ }^{66}$

While the printing press was often far too incriminating a medium, a song was a safer and highly effective alternative vehicle for stimulating lay piety and teaching believers about faith. Similarly, the New Testament booklet that Panarelli kept up his sleeve and carried around the city to take it out when he wished to recite or refresh his memory of a particular scriptural verse suggests a different set of attitudes and interactions with texts than books and Bibles held and displayed at home. It was always at hand and it could be quickly tucked away when some zealot from the Holy Office approached.

Finally, perhaps the most powerful potential of such street performances was their ability to project themselves into the domestic sphere and reach the ears of those who were otherwise inaccessible, a potential exploited in the contemporary practice of singing mattinata at night in front of people's houses, and not just for romantic purposes, while a crowd of passers-by assembled. ${ }^{67}$ In March 1607, for example, during the jurisdictional controversy of the Interdict between Venice and Rome, when signs of anti-Roman sentiments were visible everywhere, posted on the city's walls and circulated in offensive libels: 'in the middle of the night, serenades were heard outside the window of Cardinal Gioiosa, played with many musical instruments and with so many insulting songs' that the Cardinal threatened to leave Venice immediately and abandon peace negotiations. ${ }^{68}$

66 Asv, Sant'Uffizio, b. 7, Dossier 'Favretti'; b. 22, Dossier 'Giacomo-Negroni.' Seidel Menchi, "Protestantesimo a Venezia" 231-232.

67 Dennis F., "Sound and Domestic Space in Fifteenth- and Sixteenth-Century Italy", Studies in the Decorative Arts 16/1 (Fall-Winter 2008-2009) 7-19. On popular devotional texts composed, published and recited by street performers see Salzberg R., "The Word on the Street: Street Performers and Devotional Texts In Italian Renaissance Cities”, The Italianist 34 (2014) 336-348.

68 Città del Vaticano, Biblioteca Apostolica Vaticana, ms. Urb. Lat., 1075, Avvisi di Roma, fols. 136r-137v, 10 March 1607: 'Intanto altri anco avisano, che al Card. Gioiosa haveano fatto di notte una serenata con molti instromenti musicali si ma però piene de canzoni di cose et parole cattive toccanti anco il Card.le che però se n'era mostrato tanto alterato, che haveva minacciato di partirsi, et altri anco dicono ma falsamente che era partito, et la Rep.ca messo taglia di $2 \mathrm{~m}$. scudi à chi rivelava l'auttore di questo misfatto, co' prometter anco l'immunità se fosse uno de complici quell che rivela'. Cardinal Gioiosa managed to secure the peace deal between Venice and Rome on 9 April 1607. See, the letter of the French Cardinal Jacques Du Perron to the French king: Lettera scritta dal car. Di Perona al Re Xmo intorno al Trattato d'Accordo maneggiato dal card. Di Gioiosa tra Papa Paolo Quinto, e la Serenissima Rep.ca Venetia, Roma 9 Aprile 1607. Biblioteca Nazionale Marciana Classe VII. Cod. CXLIII.8951. 
Gathering around the table for food and conversation was an essential part of domestic ritual around which much of the Gemma' devotional life revolved. It provided an occasion for communal reading of the Bible and shared learning, as we have seen, but also for creating their own family rituals of celebrating the Lord's Supper at home. Such rituals included praying and singing psalms, reading from the Scriptures and sharing pieces of leavened bread, the 'real' one made with yeast in place of the unleavened consecrated Eucharistic bread. ${ }^{69}$ They could take place at the table or at people's sickbeds and even in classroom at school. At the deathbed of their co-religionist and patient the wool carder Fancesco Semprini, when they could do nothing else to save him, Silvestro and Gian Battista called in a former Franciscan friar Fidele Vico to celebrate communion with pieces of leavened bread. A master of a heretical 'schola', Vico frequented the Gemmas' pharmacy and performed similar ceremonies for his students at school. ${ }^{70}$

The Gemmas' ritual of performing the Last Supper at home subverted the whole range of devotional practices associated with the Eucharist, a crucial sacramental experience for Catholics, whether it was administered to the sick and dying at home, taken during the annual confession and communion at Easter, or worshiped as a relic quite literally of Christ's body present in the Eucharistic host. Its magical talismanic qualities were further accentuated by the paraliturgical Corpus Christi processions, during which a consecrated host was displayed and paraded through Venetian neighbourhoods. While often reduced to spectators rather than participants in the divine mysteries of the Eucharist, ${ }^{71}$ in the domestic sphere, the laity appropriated its sacramental power by acquiring consecrated wax figures of the Agnus Dei that brought the presence of

69 For celebrating the Lord's Supper in houses of Venetian patricians see Ambrosini, Storie di patrizi gon. For similar rituals performed at home 'with any normal bread' and other organised forms of sociability among the community of 'fratelli' in Modena, see Al-Kalak M., L'eresia dei Fratelli. Una comunità eterodossa nella Modena del Cinquecento (Rome: 2011).

$70 \quad$ Asv, Sant'Uffizio, b. 23, Dossier Sylvestrum Semprini, Angelam, Stephanum et Cypriani Semprini, testimony of Angela Semprini; and Dossier 'Fedele Vico'. On the Semprinis see Martin, Venice's Hidden Enemies 140-141. For Vico see Ambrosini, Storie di patrizi ad vocem; Ambrosini, "Tendenze filoprotestanti" 155-181.

71 Particularly after the Gregorian reforms of the eleventh century, which had established the clerical monopoly over the performance of the mass in Latin and restricted taking communion by the laity to prevent perversion. Vauchez, The Laity in the Middle Ages 10. 
Christ into their daily activities and were kept at homes as talismans protecting against the tricks of the Devil, diseases and other misfortunes. ${ }^{72}$

For the Gemmas, who dismissed the pageantry of Corpus Christi and the 'idolatry' of Agnus Dei, and undermined the ritualistic dogmatism and theology of the Eucharist by celebrating communion at home, it was not just the physical site and the material substance of the bread but the transformative nature of the Eucharistic sacrifice that acquired new dimension. Indeed, as they gathered together and recited the scriptural account of the Last Supper, when Jesus said 'this is my body' while breaking the bread, we may wonder what it meant for each member of this interconfessional family.

The literal or allegorical interpretation of Jesus' words and the identification of Christ's body and blood with bread and wine had been a subject of theological debates for centuries, before arriving at the concept of transubstantiation based on the corporeal interpretation of Saint Ambrose (ca. 339397), and consolidated ex Aristotle by Thomas Aquinas (ca. 1225-1274). The explicit formulation of the sacramental ingestion of Jesus's flesh, 'broken by the hands of the priests and ground by the teeth of the faithful', as the French theologian Berengar of Tours was forced to declare during the Synod of Rome in 1059, revived the ancient associations of the Eucharistic sacrifice with the ritual theopagy of the pagans and came to nourish the Protestant criticism of the Catholic rituals and doctrine of transubstantiation in the wake of the Reformation. ${ }^{73}$ While Luther elaborated his own concept of Christ's presence in the Eucharistic bread and at the same time consubstantial with the person of God, Zwingli could reconcile himself to neither Catholic nor Lutheran theology. For Zwingli, the Eucharist was a symbolic act of commemoration of Christ's salvific gift of redemption, acquired through the faith of the participants, rather than the magical transformation and consumption of Christ' body. ${ }^{74}$

As for the Gemmas, a family where Catholic, Lutheran and radical Spiritualist cultures intermingled, did they believe that something miraculous happened every time the priest performed the ceremony of the mass or when

72 Scribner R.W., "Ritual and Popular Religion in Catholic Germany at the Time of the Reformation", Journal of Ecclesiastical History 35 (1984) 47-77. See also Irene Galandra Cooper's essay in this volume, 220-243.

73 On theopagy (consumption of a deity's flesh) in the Dionysiac cult among the Greeks and its association with early Christianity, see Heinrichs A., "Pagan Ritual and the Alleged Crimes of the Early Christians", in Granfield P. - Jungmann J.A. (eds.), Kyriakon (Münster: 1970) 18-35. For Berengar see McCue J.F., "The Doctrine of Transubstantiation from Berengar through Trent: The Point at Issue", Harvard Theological Review 61 (1968) 385-430 (387).

74 On Eucharistic controversies of the Reformation, see Palmer W.L. (ed.), A Companion to the Eucharist in the Reformation (Leiden - Boston: 2014). 
they shared pieces of bread at home? Marcantonio provided an answer when he was summoned by the Inquisition to explain 'whether he believed that the consecrated host is the true body and blood of Jesus, whose presence is real and corporeal. ${ }^{75}$ According to Marcantonio, his father Silvestro (a Lutheran) did believe in the real presence of Christ in the bread, whereas he himself followed his schoolmaster, the Franciscan friar Paulo of Brescia, who taught him that the Lord's Supper was not a corporeal but merely a spiritual matter. On the other hand, Marcantonio continued, he occasionally attended the Mass and nurtured some doubts 'because I was told [perhaps by his Catholic wife Marietta] that outside the mass the Gospel does not count: ${ }^{76}$ But his radical (Spiritualist and Antitrinitarian) brother Gian Battista openly derided and mocked the sacraments saying blasphemies against the Eucharist. ${ }^{77}$ And, although Marcantonio lacked the intellectual background of his universitytrained brother, he was confident enough to challenge the corporeal presence of Christ in the Eucharist, quoting the view of Saint Augustine on this (who shunned Ambrosian literal meaning in favour of figurative 'spiritualist' interpretations of the Lord's Supper). ${ }^{78}$ When Marcantonio presented these views to his confessor, he threw an ink-set at him and refused to absolve him. But Marcantonio went home and returned 'with a book of Saint Augustine to show him that I was telling the truth, and so I was absolved. ${ }^{79}$

For the radical spiritualising circles of the Venetian Anabaptists, 'a piece of bread always remains a piece of bread', as the physician Nicolò Buccella put it

75 Asv, Sant'Uffizio, b. 20. Dossier Gio Battista e Marcantonio speziali, Testimony of Marcantonio, 2 June 1565: 'se l'ha creduto che nell'hostia consecrata dal sacerdote sia veramente il corpo et sangue del Jesu realmente et corporealmente'.

76 Ibid.: 'perchè mi era stato detto che dall'evangelio in fuor a la messa non valesse'.

77 Asv, Sant'Uffizio, b. 20, Denunciation of Francesco Camillo (spicier da vin) di San Giovann e Polo against Gian Battista Gemma, 5 May 1565: 'deride e burla li perdoni, la confessione e il S. Sacr[amen]to [...] bestemmiando la messa'.

78 Asv, Sant'Uffizio, b. 20, Testimony of Zuan de Giacomo Zapelin, 24 May 1565: 'ponteziava Santo Augustino perchè non sia el vero Corpo et Sangue di Christo'. Augustine of Hippo, De civitate Dei (10.5; 10.20, c. 426); Sermo De verbis apostoli (172. 2). Philip Schaff's reading of Augustine on the Eucharist still remains one of the best discussions of the subject: "The Patristic Doctrine of the Eucharist", The Biblical Repertory and Princeton Review 38, 1 (1866) 47-73. For an overview of the recent scholarship on the Augustinian roots of the Reformation see Ellingsen M., "Augustinian Origins of the Reformation Reconsidered", Scottish Journal of Theology 64 (2011) 13-28; and Visser A.S.Q., Reading Augustine in the Reformation: The Flexibility of Intellectual Authority in Europe, 1500-1620 (New York: 2011).

79 Ibid., 'el non mi voleva assolvere, ma io gli hò portato un libro di Santo Augustino, et li hò mostrato, che dico la verità, et cosi lui mi ha assolto'. 
bluntly. ${ }^{80}$ The Anabaptist wool carder Simone de Simoni of Vicenza was much more eloquent and declared that 'it was a great folly to believe that Christ would come inside the host and let himself be locked up in a hole in the wall or in a piece of glass or wood, and then allow himself to be eaten'. ${ }^{81}$ Quite apart from the physical impossibility that the person of Christ could be in more than one place at once, like Zwingli, he was concerned about the theological and philosophical speculations that made God the victim of a cannibalistic sacrifice.

\section{Those Who Eat Tripe and Those Who Devour God Whom They Worship}

While the Protestant radicals jested about Christians devouring their God, what one ate was of no small significance to the Catholic Church, which developed a complex symbolic system of food manipulation and did not hesitate to make pronouncements on diet, the healing powers of holy water, salt and herbs used in the sacramental rituals, or to advocate fasting as befitting the preparation of the body for the consumption of Christ in the Eucharist. Caroline Walker Bynum has shown how in the later Middle Ages female mystics expressed their devotion to the Eucharistic host through fasting as a way of 'purging' their souls and preparing the body for the physical union when 'eating God'. 82

Attention to diet was also at the heart of standard medical advice. The Hippocratic food regimen recommended certain foods as good or bad for restoring the body's healthy complexion of humours. The nutritional quality and digestibility of certain foods was of particular importance. Hence, meat, eggs and butter were considered most nutritious, digestible and 'warming' while grains, fruits and vegetables were dismissed as 'humid' and 'cold', less digestible or even poisonous. ${ }^{83}$

Thus when the post-Tridentine Church reaffirmed its dietary prescriptions for Lent and continued to tighten up its expectations of the faithful that they eat penitential fish and vegetables instead of meat and dairy products, serious

\footnotetext{
8o Asv, Sant'Uffizio, b. 19, Dossier 'Contra Anabatistas: Nicolò Buccella', Ambrogio di Rizzetto, Francesco Della Sega', 9 October 1561: 'quel sia pane, et resti sempre pane'.

81 Asv, Sant'Uffizio, b. 29, Dossier 'Simone de Simoni, filatore di seta of Vicenza,' 22 April 1570: 'è una gran pazzia credere che Christo venghi in quella hostia, et lasciassi chiudere in un buco di muro, di vetro, overo di legno, et poi lasciassi mangiare'.

82 Walker Bynum C., Holy Feast and Holy Fast: The Religious Significance of Food to Medieval Women (Berkeley: 1987).

83 Cavallo S. - Storey T., Healthy Living in Late Renaissance Italy (Oxford: 2013) 213-218 (215).
} 
concerns were raised about the healthiness of such vegetarian regimes. This was the case not just among physicians and Protestant controversialists but anyone who was concerned to protect their 'weak stomachs' or consciences from such unreasonably rigid dietary prescriptions. ${ }^{84}$ Eating and dining as he pleased, Doctor Gemma did not hesitate to offer his own medical advice to the Inquisitor who questioned his carnivorous appetite at Lent. Recommending the Hippocratic regimen of moderation and maintenance of the body's normal habits as key to healthy living, he suggested that self-restraint was only advisable to avoid food poisoning, since 'one ought to eat freely all types of food everyday though with moderation, and to abstain from meat only when one sees that it has gone off but not because it is this time or that time'.85 As his less sophisticated friends, the Semprini family, put it, 'it was not a sin to eat and evacuate' to quote their statement recorded by the Inquisition. ${ }^{86}$

It was in kitchens and stomachs that confessional identities were digested and contested, and the records of the Holy Office glaringly demonstrate that people were often judged on the basis of their dietary habits. Thus those who were caught eating meat on Fridays or eggs on Saturdays, or like the apothecary Ambrogio, 'eating meat and fatty foods prohibited by the Holy Mother Church all the time in disregard of Christian laws', were inevitably denounced as 'Lutherans', 'Jews' or 'Turks'. Detailed inquiries into the domestic economy of food preparation and consumption, Judaic rites of meat slaughter or food sharing with the Ottoman-Turkish Muslims reveal the importance of food in the forming and performing of confessional identities. One Sunday in Lent, when Isabetta entered Ambrogio's house accompanying his sister Angela, she saw the apothecary in the company of a certain Giacometto and his garzon Filippo all eating tripe ('magnavano delle trippe'). She became even more disconcerted when Angela showed real or feigned ignorance of the Lenten prohibitions and explained as a matter of fact that her brother enjoyed 'eating tripe without a pie' ('l'haveva senza pizza'). ${ }^{87}$

When a court registrar Nicolò Guidozzo of Castelfranco entertained a guest for dinner, serving a plate of lasagne cooked in a chicken broth ('un piatto di lassagne cotte nel brodo di carne') in disregard of the Lenten prohibitions, in

84 Ibid., especially the section "Vegetables, Lent, and Health" 213-218. For a shift towards vegetarian regime in the Counter-Reformation period, see also Gentilcore D., "The Levitico, or How to Feed a Hundred Jesuits" Food and History 8, 1 (2010) 87-120.

85 ASv, Sant'Uffizio, b. 20, Testimony of Gianbattista Gemma, 17 May 1565.

86 Asv, Sant'Uffizio, b. 23, Testimony of Padre dell'Ordine di San Francesco: Fra Paolo da Venetia, 24 November 1567: 'non essere peccato quello che entro nella bocca, ne quello che esce'.

87 Asv, Sant'Uffizio, b. 22, Testimony of Donna Isabetta, 20 December 1567. 
response to his guest's pious concerns he proposed that 'these we will baptise as plain fritters' ('queste le batizermo per fritole'). When serving a whole roast chicken he continued 'we shall re-baptise it as grey mullet' ('questa ribattizaremo per bolpina'). ${ }^{88}$ Like his cuisine, Nicolò's mock ritual betrayed his religious identity, which the Holy Office would have found particularly indigestible one that centred on the Anabaptist practice of re-baptism and rejection of infant baptism, a sacramental rite of initiation into the Christian church and society. Like the Anabaptist withdrawal from the civic state, it was seen as an act of political rebellion and anarchy, particularly after its violent expression in the short-lived apocalyptic Kingdom of Münster in $1533-1535 .^{89}$ Coupled with the biblical literalism and pauperism of the Church of the Apostles, it would not take long before the Venetian Anabaptists would link their nonconformist religious views to a radical social critique of the prevailing economic and social conditions of society.

The unleavened Eucharistic bread was called the 'bread of affliction' because it was made and eaten in haste before the Exodus (there being no time to let it rise). Thus when Piero, the apothecary at the sign of the Moon, was defending his poor co-religionists who celebrated the Lord's Supper with leavened bread, he compared the ecclesiastical efforts to eradicate these domestic rituals to the efforts of nobles to impose a coarse diet - the 'bread of affliction' - on their peasants. He observed that 'friars and priests are of the same breed as nobles, for they deceive the peasants by telling [them] that whoever eats leavened bread will end up in Hell, and so they, too, make what is good [eating more nutritious risen bread] appear bad.9 ${ }^{90}$ In early modern society food was a crucial differentiator of social and economic status. with 'high-growing' game, birds and fruit suited for the tables of the highborn, and earthly pork, cereals and root vegetables for the stomachs of the lowly. Thus the 'poor' vegetarian diet prescribed by the Church for the Lent not only endangered personal health, but appeared to reinforce class prejudices.

Medical learning and identities certainly played a part in expelling 'unhealthy' Lenten food regimes from one's kitchen, or dismissing the healing powers of holy images, or inviting free love into one's bedroom - another area of contention and incursion of the Church into intimate domestic affairs. In medical thinking, sexual intercourse was conceptualised for men as a form

88 ASv, Sant'Uffizio, b. 40, Dossier Nicolò Guidozzo, testimony of Giorgio Griffoni, 10 January 1576. Cf. Seidel Menchi, Erasmo in Italia 111. Seidel Menchi was the first to frame her discussion of the redefinition of the sacred in the context of food culture.

89 La Rocca T. et al. (eds.), Thomas Müntzer e la rivoluzione dell'uomo comune (Turin: 1990); Goertz H-J., The Anabaptists trans. T. Johnson (London: 1996).

90 Asv, Sant'Uffizio, b. 40, Dossier 'Contra Petrum a Luna aromatarium', 13 March 1576. 
of purging which was necessary to maintain a healthy balance of bodily humours, and often discussed outside the Christian moralistic view of human sexuality. In his dialogue Examen omnium, inspired by Erasmus's Colloquia, the noted botanist Antonio Musa Brasavola (1500-1555) of Ferrara offered a remarkable defence of sensual love against contemporary opinions that sexually transmitted diseases such as syphilis were God's scourge sent to punish humanity for its sexual excesses. Conversing with the old apothecary Senex, the author declared that

if God is angry only with the lustful, why isn't he also angry with usurers, thieves, blasphemers, and murderers, whose sins are far worse than those of a man who, perhaps unmarried himself, had coitus with an unmarried woman? To practise sensual love is natural for each and every one of us, and, when comparing this to the other [sins], it is an [inherently] human act by counsel and commandment, whereas murdering, looting, stealing, and blaspheming as a whole is against nature. And if God was displeased so much with men enjoying sexual contact, he could simply inhibit their [penile] erection, so that their wishes to make sensual love would have come to nothing. ${ }^{91}$

Mingled with hundreds of pharmaceutical prescriptions and couched in technical medical vocabulary, Brasavola's statement remained 'hidden' from the censors. But it would have been easily accessible to apothecaries such as Gian Battista ssssGemma, who himself resented the Church's interference into his intimate domestic affairs. Standing before the Inquisition, he declared that like all other obligations, vows of chastity were impossible to uphold, and it was a folly to make any vows or pay for pilgrimages when one had to look after one's household'. ${ }^{92}$

Beyond an intriguing vignette about early modern perceptions of healthy food, sensual love, marriage, sociability and domesticity, our panoramic view

91 Brasavola Antonio Musa, Examen omnium loch, id est, linctuum suffuf, id est, puluerum, aquarum, decoctionum, oleorum, quorum apud Ferrariensis pharmacopôlas vsus est: His accessit de morbo Gallico [...] tractatus (Lugduni, apud Sebastianum Bartholomei Honorati: 1554), 'De morbo gallico' 508-509: 'si Deus in luxuriam invectus est, in foeneratores invectus non est, in grassatores, in latrones, in blasphemas, in homicidas, qui seuiora mala perperrant, quam qui coitu utuntur, quam si solutus cum solute iungatur. Nam Venerem exercere unicuinque, naturale est, hanc vero vel illam sibi deligere, est consilio et praecepto factum hominem vero interficere, grassari furabi, blasphemare, sunt a toto genere praeter naturam: Siq; Deo tantum displiceret, ut homines Venere uterentur, posset ilico ab ipsis tentiginem auferre, et nullus inveniretur, qui Venere uti vellet'. Asv, Sant'Uffizio, b. 20, Testimony of Gian Battista Gemma, 17 May 1565. 
of devotional life of the Venetian apothecaries should convince us that domestic piety was far from being an uncontroversial activity. In the intersecting worlds of Catholics and Protestants in Venice, where people of all faiths rubbed shoulders, it was sometimes difficult to find a sense of privacy, solitude and introspection, while personal devotion could easily become a disruptive force within one's neighbourhood, street or even home. As the case of the Gemma family reveals, each individual negotiated their relationship with the sacred in accordance with their own notions of inner spiritual or external physical space where one meets with God. And while the Lutheran Silvestro Gemma endures the materialist, theatrical, and ceremonial torture of the Corpus Christi procession, he inflicts a similar mental anguish on his daughter-in-law Marietta and her Catholic sensibility.

Beyond the problems of obvious doctrinal differences, iconoclasm, and gender and generational conflicts, there were also areas of mutual influences and confluences, not always acknowledged in accounts of domestic piety. While 'getting along' more or less peacefully, confessional boundaries were constantly transgressed, while the need for compromise and adaptation became paramount, as Marcantonio Gemma's habit to accompany his wife Marietta to the church but only 'to hear the Gospel in disregard of the rest of the Mass' shows us. ${ }^{93}$ In a constant process of sacralising and desacralizing domestic spaces, rituals and objects, various heterogeneous practices developed, like the clandestine production of crucifixes 'painted in a Lutheran fashion' but moulded out of wax - a quintessentially 'interconfessional' devotional material that was easily available at pharmacies for the production of votive figures, Agnus Dei and funeral torches. ${ }^{94}$ This in turn teaches us that we should not underestimate the confounding eclecticism and subjectivities of everyday life in forming and performing religious identities, and that the traditional historiographical frameworks and rigid confessional categories of the Protestant and Catholic Reformations do not suffice to account for the extraordinary richness and complexity of religious attitudes in sixteenth-century Italian homes and cities.

\section{Selective Bibliography}

\section{Primary Manuscript and Printed Sources}

ASV - Archivio di Stato, Venice.

BAV - Città del Vaticano, Biblioteca Apostolica Vaticana, Rome.

93 ASV, Sant'Uffizio, Testimony of Marcantonio, 2 June 1565.

94 Asv, Sant'Uffizio, b. 6, Dossier 'Il Colombina'. 
Alberto da Castello, Rosario della Gloriosa Vergine Maria (Venice, Marchio Sessa \& Piero di Rauani compagni: 1522).

Brasavola Antonio Musa, Examen omnium loch, id est, linctuum suffuf, id est, puluerum, aquarum, decoctionum, oleorum, quorum apud Ferrariensis pharmacopôlas vsus est: His accessit de morbo Gallico [...] tractatus (Lugduni, apud Sebastianum Barptolomei Honorati: 1554).

Gemma Joannes Baptista, Methodus rationalis novissima, atque dilucidissima curandi bubonis carbunculique pestilentis [...] (Graecij Styriae, Ioannes Faber: 1584).

La Biblia quale contiene i sacri libri del Vecchio Testamento, tradotti nuovamente da la hebraica verità in lingua toscana da Antonio Brucioli [...] (Impresso in Vinegia, ne le case di Lucantonio Giunti fiorentino: 1532).

Sant'Uffizio, b. 7, Dossier 'Favretti'.

Sant'Uffizio, b. 19, Dossier 'Contra Anabatistas: Nicolò Buccella', Ambrogio di Rizzetto, Francesco Della Sega'.

Sant'Uffizio, b. 20, Dossier 'Zuanbattista Gemma'.

Sant'Uffizio, b. 22, Dossier 'Giacomo-Negroni'.

Sant'Uffizio, b. 23, Dossier 'Sylvestrum Semprini, Angelam, Stephanum et Cypriani Semprini'.

Sant'Uffizio, b. 23, Dossier 'Fedele Vico'.

Sant'Uffizio, b. 37, Dossier 'Gemma, Giò Battista; b. 80, Dossier 'Per Domo Marco, Gemma Aurora'.

Sant'Uffizio, b. 40, Dossier 'Contra Petrum a Luna aromatarium'.

Sant'Uffizio, b. 77, Dossier 'Giorgio Francesco Diaz'.

Sant'Uffizio, b. 159, Dossier 'Contra fra Danielem de Brixia'.

Urb. Lat., 1075, Avvisi di Roma.

\section{Secondary Literature}

Addante L., Eretici e libertini nel Cinquecento italiano (Rome - Bari: 2010).

Al-Kalak M., L'eresia dei Fratelli. Una comunità eterodossa nella Modena del Cinquecento (Rome: 2011).

Ambrosini F. Storie di patrizi e di eresia nella Venezia del '50o (Milan: 1999).

Barbierato F., Politici e ateisti. Percorsi della miscredenza a Venezia fra Sei e Settecento (Milan: 2006).

Fortini Brown P., Private Lives in Renaissance Venice: Art, Architecture, and the Family (New Haven and London: 2004).

Bornstein D., "Spiritual Kinship and Domestic Devotions", in Brown J.C. - Davis R.C. (eds.), Gender and Society in Renaissance Italy (New York: 1998) 173-192.

Camporeale S.I., Lorenzo Valla. Umanesimo e teologia (Florence: 1972).

Cavallo S., "The Artisan's Casa", in Marta Ajmar-Wollheim and Flora Dennis (eds.), At Home in Renaissance Italy, exh. cat. (London: 2006) 352-355. 
Cavallo S. - Storey T., Healthy Living in Late Renaissance Italy (Oxford: 2013).

Dennis F., "Sound and Domestic Space in Fifteenth - and Sixteenth-Century Italy", Studies in the Decorative Arts 16/1 (Fall-Winter 2008-2009) 7-19.

Fenlon I., Music and Culture in Late Renaissance Italy (Oxford: 2002).

Firpo M., Riforma protestante ed eresie nell'Italia del Cinquecento. Un profilo storico (Rome: 1993).

Fragnito G., La Bibbia al rogo. La censura ecclesiastica e i volgarizzamenti della Scrittura (1471-1605) (Bologna: 1997).

Kostylo J. "Pharmacy as a Centre for Protestant Reform in Renaissance Venice", Renaissance Studies 30/2 (2015) 236-253.

Martin J.J., Venice's Hidden Enemies (Berkeley - Los Angeles: 1993).

Mazzonis Q., Spirituality, Gender, and the Self in Renaissance Italy (Washington D.C.: 2007).

Muir E., Civic Ritual in Renaissance Venice (Princeton: 1981).

Palumbo Fossati I., Dentro le case. Abitare a Venezia nel Cinquecento (Venice: 1984).

Pollmann J., "Hey Ho, Let the Cup Go Round!' Singing for Reformation in the Sixteenth entury”, in H. Schilling H. - Tóth I.G. (eds.), Cultural Exchange in Early Modern Europe (Cambridge: 2006) vol. 1: 294-316.

Seidel Menchi S., Erasmo in Italia: 1520-158o (Turin: 1987).

Scribner R.W., For the Sake of Simple Folk: Popular Propaganda for the German Reformation (Cambridge: 1981).

Stella A., Anabattismo e antitrinitarismo in Italia nel XVI secolo. Nuove ricerche storiche (Padua: 1969).

Trinkaus Ch., In Our Image and Likeness: Humanity and Divinity in Italian Humanist Thought (Notre Dame: 1995).

de Vivo Filippo, "Pharmacies as Centres of Communication in Early Modern Venice", Renaissance Studies 21/4 (2007) 504-552.

Wandel L.P., (ed)., A Companion to the Eucharist in the Reformation (Leiden - Boston: 2014). 